\title{
Crafting interdisciplinary in an M.Sc. programme in management of natural resources and sustainable agriculture
}

\author{
by Paul Vedeld ${ }^{1}$ and Erling Krogh ${ }^{2}$
}

\begin{abstract}
This paper discusses challenges of an educational program, where interdisciplinarity is an important ambition. A theoretical perspective on interdisciplinarity must be more than adding insights from different disciplines as surprisingly many actors still take it to be. Interdisciplinarity is a fruitful meeting-ground and constitute processes for translation and integration of disciplinary perspectives. Interdisciplinary candidates must learn and should develop skills to identify, select, translate and integrate knowledge from different disciplines into a coherent framework. From theories in interdisciplinarity, one should develop explicit theories for interdisciplinarity. A common field focus can motivate integration of and translation between disciplines. The multipurpose re-orientation in forestry as an example of natural resource management displays the need for development of management proficiency not only related to multipurpose management, but also to handle social issues and interactions between conflicting actors. Within forestry, interdisciplinary challenges are often met through implicit, tacit and experience-based "common sense" knowledge. An explicit focus on integration of and translation between disciplines as well as development of experience-based skills is required to build interdisciplinary proficiency. This includes using practical field assignments and problem-based learning approaches to develop candidates' abilities to select, translate and integrate knowledge.
\end{abstract}

Key words: interdisciplinarity, environment and development, cross-epistemic communication, natural resource management and education

\section{RÉSUMÉ}

Cet article fait état des défis retrouvés au sein d'un programme de formation, où l'interdisciplinarité constitue un point central. Une perspective théorique sur l'interdisciplinarité doit être plus que l'ajout d'éléments propres à chacune des disciplines comme étonnamment plusieurs acteurs estiment qu'il se doit. Les candidats issus de diverses disciplines doivent apprendre et développer des habiletés pour identifier, sélectionner, transposer et intégrer les connaissances provenant de différentes disciplines pour constituer un cadre de travail cohérent. À partir des théories sur l'interdisciplinarité, des théories explicites de l'interdisciplinarité doivent également être élaborées. Une concentration sur un domaine commun peut motiver l'intégration et la transposition entre les disciplines. La ré-orientation à objectifs multiples vécue en foresterie en tant qu'exemple de l'aménagement des ressources naturelles fait état de la nécessité de développer une compétence en matière d'aménagement reliée à la fois à l'aménagement polyvalent et à la gestion des enjeux sociaux et des interactions entre les acteurs en conflit. En matière de foresterie, les défis reliés à l'interdisciplinarité sont souvent résolus par l'entremise de connaissances tacites et reposant sur le « bon sens ». Une attention particulière sur l'intégration et la transposition entre les disciplines ainsi que le développement d'habiletés basées sur l'expérience est requise pour établir une compétence interdisciplinaire. Cela comprend l'utilisation d'assignations pratiques sur le terrain et des approches d'apprentissage à partir de problèmes afin de développer les habiletés des candidats à sélectionner, transposer et intégrer les connaissances.

Mots clés : interdisciplinarité, environnement et développement, communication inter-épistémique, aménagement des ressources naturelles et formation académique

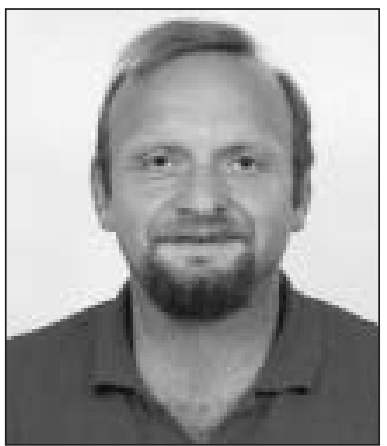

Paul Vedeld

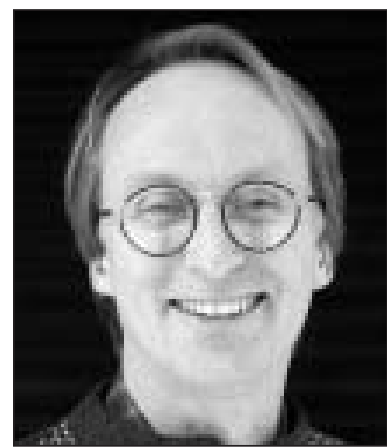

Erling Krogh

\section{Introduction}

Reflective natural resources management presumes knowledge about ecosystem dynamics and about human, sociocultural, political, economic and legal systems. It also seems important to address various ways to understand both practical use and more scientific management of natural resources.

Is it at all possible to craft interdisciplinary higher education programmes on management of natural resources that

\footnotetext{
${ }^{1}$ University of Life Sciences, Norway, Department of Environment and Development Studies, Noragric. E-mail: palve@umb.no Corresponding author

${ }^{2}$ University of Life Sciences, Norway.
} 
provides theoretical knowledge and experience-based skills? That includes both natural and social sciences? What challenges arise in the process of planning and implementing such an interdisciplinary programme? Such questions are handled in this paper, through using the case of a M.Sc. programme in Natural Resource Management and Sustainable Agriculture (MNRSA) launched at the Agricultural University of Norway in 1986.

To teach students disciplines with different theoretical and methodological traditions in the same study is an obvious challenge. The challenge is not made easier by a rather ambitious intention of the study to "develop candidates with theoretical knowledge and experience-based competence to handle natural resource management in developing countries." The candidates are in addition recruited from very different countries with different cultural, social and educational backgrounds. In the programme, we have consciously tried to develop explicit and theoretical underpinned interdisciplinarity - open for constructive and critical dialogue between scientific staff themselves and with students on the programme and the various fields involved.

This paper begins with a presentation of the programme. This is followed by a discussion of the structure and development of the programme since its inception in 1986. The development process of the programme reflects an experience-based change, with an evolution of increased consciousness about definitions, preconditions, and practical solutions for an interdisciplinary programme. The paper offers approaches and experiences that could be of use for similar study programmes. We also use our experiences for more general reflections on theoretical and also practical ways to approach interdisciplinary studies.

Over the last 15 years, the programme has graduated almost 600 M.Sc. students. Similar M.Sc. programmes/courses are now running at co-operating institutions in developing countries such as Tanzania, Kenya, Ethiopia, Uganda, Pakistan and in Nepal, often with active involvement from previous students.

\section{Students Scientific Portfolio as Preconditions for Interdisciplinary Training}

The widespread geographical recruitment to the programme provides substantial cultural and educational diversity. Teaching students (and often staff) to draw on this diversity requires actively facilitating a development from "mono-cultural" discipline-oriented minds to more open-minded candidates able to both learn and practise an interdisciplinary approach to natural resource management.

As an example, in the first semester the students attend a course in resource economics. Using the heterogeneous student mass as an instrument, we split the newly arrived students into groups according to their scientific background. A group of foresters and a different group of social scientists were asked to answer the same three questions on overgrazing in Africa (Table 1).

The differences were more striking than anticipated. The responses show a systematic difference in focus and in how the disciplinary groups describe, explain and prescribe a particular environmental problem. The foresters focus on nature, ecological systems and "welfare of nature." The economists focus on human adaptation, social systems and "welfare of man." In the start-up of the MNRSA programme, the staff struggled in similar ways to co-ordinate and link disciplinary approaches.

In the environmental and development field, where economists and ecologists meet, we see that proponents of the two disciplines meet as they study the "same" object in the real world, but with very different epistemic frameworks (Vedeld 1994). Within a discipline, there are sanctions and norms to conform researchers to stay together and allow for cumulative

\section{Box 1. Goals and content of programme}

The major theoretical goal is to develop a fruitful combination of theoretical knowledge and experience-based approaches that contributes towards better understanding of "nature-society relationships." The major proficiency goal is that such knowledge should enable institutions and candidates to interpret and be able to generate practical processes of social change in terms of empowerment, equitability and sustainability. The program also includes an attitude goal where candidates should develop their ability to think critically and analytically and communicate effectively.

The programme encompasses an interdisciplinary perspective on natural resource management and environmental problems with a focus on natural eco-systems and primary sectors (agriculture, forestry, fishery, wildlife, pastoralism etc.) and how people as individuals and in social contexts co-operate or conflict over access and use of resources. The interdisciplinary approach thus has to address an understanding of the multi-layered nature of such processes and larger issues of governance, power use, authority lines, rights and duties and the complex structures and processes framing the multiple arenas where decisions over resource use take place.

\section{Structure and Process}

The MNRSA is a course/module based-program over four semesters. The first semester is mostly, but not only multi-disciplinary, students are introduced to what are core supporting courses in tropical ecology, resource economics, social anthropology and statistics. The second semester is clearly more interdisciplinary. The main course in management of natural resources forms the core of this semester, with emphasis on more theoretical multi and interdisciplinary aspects. In the third semester, there is an even more applied inter- and transdisciplinary ambition. Students are sent to Uganda or Nepal for seven weeks of course-work in a sandwich model, being exposed to a developing country university environment. This is followed by a further three months field work as a basis for writing their theses. The last semester is spent at UMB. Here they again meet in a weekly writing seminar while working on their thesis. In addition they take a course in political ecology. At the end of the semester they are expected to put forward and defend their thesis in public settings. 
Table 1. Group-work in the MNRSA-programme on challenges of interdisciplinarity

\begin{tabular}{|c|c|c|}
\hline Task & The forester/biologist group & The social scientist group \\
\hline $\begin{array}{l}\text { 1. Describe the problem } \\
\text { of overgrazing in Africa } \\
\text { in maximum } 5 \text { points. }\end{array}$ & $\begin{array}{l}\text { 1. Reduced vegetation cover } \\
\text { 2. Low infiltration capacity } \\
\text { 3. Reduction in biodiversity } \\
\text { 4. Reduction in regeneration } \\
\text { 5. Increased soil erosion }\end{array}$ & $\begin{array}{l}\text { 1. Loss of livelihood, increased food insecurity } \\
\text { 2. Lower incomes affect productivity } \\
\text { 3. Increased disease due to lack of food } \\
\text { 4. Migration } \\
\text { 5. Social conflicts }\end{array}$ \\
\hline $\begin{array}{l}\text { 2. Explain the problem through } \\
\text { ranking three main factors } \\
\text { causing the problem. }\end{array}$ & $\begin{array}{l}\text { 1. Change in grazing practice } \\
\text { 2. Increase in livestock numbers } \\
\text { 3. Lack of palatable species in area }\end{array}$ & $\begin{array}{l}\text { 1. Cultural values of livestock - prestige } \\
\text { 2. Increasing human population } \\
\text { 3. Market forces, price of meat }\end{array}$ \\
\hline $\begin{array}{l}\text { 3. Outline a solution through } \\
\text { ranking three main factors } \\
\text { or instruments. }\end{array}$ & $\begin{array}{l}\text { 1. Destocking } \\
\text { 2. Stall feeding } \\
\text { 3. Zoning for rotational grazing }\end{array}$ & $\begin{array}{l}\text { 1. Education awareness and extension services } \\
\text { 2. Diversified income generating activities } \\
\text { 3. Government policy on destocking and family planning }\end{array}$ \\
\hline
\end{tabular}

knowledge generation - what Kuhn (1969) terms puzzlesolution activities. Cross-epistemic encounters between disciplines is one possible way to establish common languages, platforms, arenas and processes where various types of "border crossing" are facilitated.

Through our teaching and supervision of students, the staff has gradually experienced and recognized that fertile cross-epistemic encounters based on interdisciplinary competence evolve as a maturing process. The students' monodisciplinary background first of all presumes a rather substantial insight in other disciplines in order to be able to see how different perspectives can be used relative to natural resource management.

In the first semester, the students therefore attain competence in core sciences in the field of natural resource management and sustainable agriculture: ecology, agronomy, economics and anthropology. Only with such core competence can they be able to approach, comprehend and execute issues that presuppose explicit translation between and integration of different sciences. Thus, the learning process begins with a multi-disciplinary approach to interdisciplinarity. We do, however, plant seeds of interdisciplinary thinking, by a weekly seminar where students themselves face topics and discuss interdisciplinary issues, preparing a process of opening the students' minds. The staff also draw lines between the disciplines in the classroom teaching.

\section{From Multidisciplinarity to Translation between and Integration of Disciplines}

Applied research related to management of natural resources is often approached by scientists from different fields. Such multidisciplinary efforts related to the same area are, however, often not very coordinated. The scientific findings in the different sciences on the same topics in many cases lead to comparisons by involved scientists-especially concerning empirical findings and discoveries (often less on comparing more basic theoretical and methodological matters). Multidisciplinarity often becomes "the mother of interdisciplinarity" in the sense that researchers initially become interested in empirical findings generated in other sciences, and then start to read up and develop more sophisticated approaches to both utilize findings and develop new theoretical and methodological perspectives.
The MNRSA programme has a structure where students go through similar processes of learning and reflection, but with to some degree more explicit focus on theory and methodology discussions. The second semester offers deeper insight in management and policy challenges, also with an emphasis on how different disciplines, perspectives and narratives individually and combined can be used to understand and handle challenges in the field (see next subsection). Competent candidates, however, should not only think well, but must also be able to perform in field. Interdisciplinary, or even transdisciplinary, competence also presumes skills or proficiency and closeness to practice. In the third semester, we thus send students for studies at a third world university (Thribuvan, Nepal and Makerere, Uganda) where they are exposed to the field by studying local communities, conflicts and development projects. This is followed by a further three months of field work as a basis for writing their theses. In a later section, we give a further socio-cultural and phenomenological argument or account for the creation of interdisciplinary competence and transepistemic communication related to these field activities.

\section{Integration of Knowledge}

Inter-disciplinarity differs from multi-disciplinarity by the integration of knowledge through various types of border crossing between sciences (Apostel et al. 1972). Inter-disciplinary efforts thus surpass mere additive approaches. The integration in production, education and application is an important component in knowledge creation.

Through acquiring knowledge in the core sciences of the programme, through field experiences and in interdisciplinary teaching, we experience that attempts to transcend or even further to "remove" disciplinary borders are both problematic and difficult. First of all, there are, within disciplines, fine-tuned and precise distinct theories, models, metaphors and methods for the study of "their particular objects" within natural resource management. In certain fields and for particular phenomena, it seems impossible to conduct direct comparison or even translations of research approaches and results precisely because they are generated within different logic epistemic frameworks and these frameworks may be incommensurable or even incompatible, following Kuhn (1969) and Bernstein (1983) (see Table 1). 
Secondly, we also experience, again with reference to Kuhn and Bernstein, that scientific traditions are not only abstract logic systems, but they are also constructed by man and form social institutions partly entrenched in particular values, norms and codes for behaviour. Attempts to transcend boundaries are often not met with open and curious minds, but with hostility and resistance-both from individual researchers who have to scrutinize or contemplate their own positions and behaviour and also from scientific environments at large. And to be honest, our own "degree of success" is also to some degree limited, in that these types of reactions are not uncommon among our own staff.

Our experimental learning in the programme has led to the application of what Lattuca (2002) names a "disciplinary approach" to interdisciplinarity, in contrast to a postmodernist view where the disciplines are "not central to the modes of enquiry." Knowledge is constructed under a "disciplinary matrix" and must be interpreted and used in that perspective. This is a crucial realisation. There is no unconditional knowledge, as knowledge is generated within particular frameworks. "Reality" is always addressed from different perspectives. Any interdisciplinary quest has to acknowledge this. In a process perspective, however, we still believe that for particular problems and even fields, we need to move beyond singular disciplinary boundaries and perspectives, but keeping in mind that translation and integration has to be done in coherent or consistent ways.

In light of such challenges of translation and comparisons, we use a number of theoretical and practical approaches to natural resource management that promotes such ambitions. We thus teach and apply a conscious choice of recent disciplinary and interdisciplinary approaches within the environment and development field to facilitate cross epistemic encounters and the development of relevant interdisciplinary competence (Table 2).

They emanate from research environments working with interdisciplinarity such as Institute for Development Studies in Sussex, University of East Anglia and Wageningen, International Institute for Environment and Development, London, University of Essex to mention some. Interestingly, many of the approaches are not explicit about the relationship to interdisciplinarity, but are more often empirically problem-based or driven.

An important issue in the stated disciplinary approach to interdisciplinarity is to organize and systematize integration of sciences and knowledge. As we partly share Klein's (1990, 1996) understanding of interdisciplinarity as a knowledge integrative activity, we have used her distinction between unifying, diversifying and synthesizing integration in our programme to deepen or improve the understanding of what integration really is about.

Unifying integration may be defined as "the application of a single theoretical perspective on to a wide range of previously distinct disciplines" (Boden 1996). In such cases, the knowledge is reconfigured, where theories and research areas are reshaped for new purposes. Unifying integration could also be used within disciplinary activities.

In the MNRSA programme, systems theory is used within several student courses, including ecology, political ecology, social anthropology and agricultural production systems. Another example is the application of rational choice or, alternatively, a social constructivist framework for analysing human behaviour in natural resource management found in different social science disciplines.

Diversifying integration "allows the heterogeneous quality of science to be maintained, and knowledge is integrated through "developing knowledge bridges and platforms." Such explicit integration links heterogeneous types of knowledge better than more traditional disciplinary science tend to do. Such integration broaden our knowledge base. There are of course numerous examples of this also within a discipline, linking sub-disciplines and linking knowledge sets between natural sciences, such as within biotechnology. But having an explicit and conscious perspective on what this integration implies from an epistemological point of view is seldom found within a discipline.

In environmental politics, the MNRSA programme explicitly stresses how physical properties of natural resources impact upon the choice of policy instruments. If there is rivalry in consumption of a good, such as for livestock and grazing, the fact that the same grass cannot be eaten by two animals, has implications for the choice of management system. Also, if the physical properties of the resource prevent users from excluding others from the use, this may have bearings for choice of management system for the resource (Randal 1987, Vedeld and Vatn 1999). To take account of such rivalry in consumption or lack of excludability requires a knowledge link. The political scientists must have the ability to see how ecological conditions frame the particular problem. And the ecologists need to understand how a human agency responds to possible "technical ecological solutions" to the problem.

Synthesizing integration occurs when "new quality of knowledge is generated from simpler forms of knowledge." This would generate new knowledge from two or more qualitatively different types of knowledge ("amalgation").

In the MNRSA-programme we show how findings pertaining to non-equilibrium ecological models for rangeland grass production and developments within game theory have bearings for concepts of optimal stocking rates in rangeland economics and management. It should also affect practical rules for handling carrying capacity as a conceptual tool in animal husbandry/rangeland management.

In the study programme, the management focus opens for unifying, diversifying and synthesizing integration of knowledge from core sciences. These integrative activities are primarily cognitive. The importance of and need for interdisciplinarity is still most visible in practical contexts-in actual management.

Interdisciplinarity is, however, more than integration. With problems of especially incompatible and partly incommensurable sets of knowledge, generated under different epistemic frameworks, interdisciplinarity is not only about integration, but involves both cognitive and normative translation, interpretation and innovative transformation processes between sets of knowledge, carefully securing coherence. This also reflects a more comprehensive and hermeneutic socio-cultural perspective.

\section{The Proof of the Pudding Lies in the Eating}

Heidegger (1977), one of the founders of modern phenomenology, wrote once emphaszizsed that individuals create meaning "entering the world." In meeting with active man- 
Table 2. Theoretical approaches used to facilitate interdisciplinary practice

\begin{tabular}{lll}
\hline Approach & Examples of application & Interdisciplinary elements \\
\hline The livelihood approach & $\begin{array}{l}\text { Rural development, Poverty } \\
\text { and environment }\end{array}$ & $\begin{array}{l}\text { It links agronomic perspectives on production to } \\
\text { house-hold level economic decision-making and to } \\
\text { wider socio-cultural and political factors that impact } \\
\text { on livelihoods. }\end{array}$ \\
\hline
\end{tabular}

\begin{tabular}{lll}
\hline Stakeholder analyses & $\begin{array}{l}\text { Protected areas and people, Rural } \\
\text { development, Dev. Project }\end{array}$ & $\begin{array}{l}\text { How rights, returns, responsibilities, relationships are } \\
\text { shaped by properties of the resources itself. }\end{array}$
\end{tabular}
assessments

Systems approaches Carbon sequestration, Rangeland
and people, Farming systems

\begin{tabular}{lll}
\hline $\begin{array}{l}\text { Farming and production } \\
\text { ystems approaches }\end{array}$ & $\begin{array}{l}\text { Crop diversification, Rural } \\
\text { development }\end{array}$ & $\begin{array}{l}\text { The interlinkages between economic systems and } \\
\text { actors' economic reasoning and the natural science } \\
\text { base and agronomic reasoning. }\end{array}$ \\
\hline Entitlement/ endowment approaches & $\begin{array}{l}\text { Diversification differentiation, } \\
\text { Environmental entitlements }\end{array}$ & $\begin{array}{l}\text { The entitlement approach helps to link economic, } \\
\text { agronomic and social perspectives from entitlement } \\
\text { mapping to endowments. }\end{array}$ \\
\hline The narrative approach & $\begin{array}{l}\text { Development strategies, } \\
\text { Environmental policy strategies }\end{array}$ & $\begin{array}{l}\text { How different narratives can be shaped by differential } \\
\text { understanding of natural and social phenomena such } \\
\text { as the deforestation debate in Africa. }\end{array}$ \\
\hline Common pool theories & $\begin{array}{l}\text { Managing village commons, } \\
\text { Rural credit systems }\end{array}$ & $\begin{array}{l}\text { How physical properties of resources are crucial for } \\
\text { tenure and other institutional arrangement around the } \\
\text { management of the resource. }\end{array}$ \\
\hline Rights-based development & Local people /protected areas & $\begin{array}{l}\text { Understanding rights presumes good understanding } \\
\text { of physical aspects of natural resources. }\end{array}$ \\
\hline Social and others kinds of capital & $\begin{array}{l}\text { Rural development / } \\
\text { local heterogeneity }\end{array}$ & $\begin{array}{l}\text { Linking capitals leads attention to complex interactions; } \\
\text { also between disciplines. }\end{array}$ \\
\hline Actor-structure networks & & $\begin{array}{l}\text { How one in research understands farmers' encounters } \\
\text { with both social and natural science based advise. }\end{array}$ \\
\hline
\end{tabular}

Joint perspective on systems that can bind perspectives from different disciplines; but systems can also contain information from different disciplines that must be harmonized. agement of natural resources, it becomes clear that monodisciplinary approaches are insufficient if socio-cultural, economic and ecological sustainability is the goal. Interdisciplinary approaches emanate as the possible answer when one "approachinges the matter itself" to quote Edmund Husserl (1913).

Interdisciplinary knowledge is also created in such fields of practice, according to Brun et al. (2002) who states that one must cater for both theoretical and experience-based practical knowledge. According to Brun et al. (2002), interdisciplinarity should furthermore be understood relative to epistemic communities and epistemological networks where knowledge is generated (see Knorr-Cetina 1981, Dreyfus and Dreyfus 1986, Latour and Woolgar1986). This implies that attention around useful competence development for candidates in natural resource management should be directed towards:

Relevant types of knowledge - In addition to abstract conceptual and technical understanding; tacit knowledge (Polanyi 1966), knowledge in action (Molander 1996) and every-day lay knowledge (Furnham 1988). Understanding of and competence in such types of knowledge seems to presume a link between theoretical and field-level knowledge.

Local knowledge - Understanding local knowledge encompasses both theoretical cultural knowledge and also experience in how the local knowledge is expressed in action and in social contexts concerning natural resource management; as proficiency.

Communication between different modes of knowledge - Interdisciplinarity encompasses both communication between disciplines and between theoretical knowledge, other types of knowledge and local patterns for behaviour. This is also termed transdisciplinarity.

In the MNRSA programme we try to build insights in interdisciplinary knowledge regimes in different ways. Students are exposed to theories on tacit and indigenous knowledge in anthropology classes, in classes on agricultural production systems and in ecology. In the third semester, students interact with local people in addition to be exposed to more practical and experience-based challenges in natural 
resource management that force them to utilize their insights in different disciplines. They have to integrate and synthesize their knowledge, through field courses and through carefully supervised fieldwork. In the last semester, they approach the complex realities of natural resource management through seminars and thesis writing.

\section{Where Have All The Flowers Gone?}

We have in several studies (Waktola and Dejene 2004) and through own experiences, especially in institution-building programmes, investigated the destiny of our students. In a study from Ethiopia, we find that many have become senior officials in public service $(20 \%)$ or professionals in universities $(25 \%)$ and research institutions often with Ph.D. degrees from our university or other institutions. Many have joined the national and international NGO sector (41\%), tempted by better pay and working conditions, and many have also sought their fortune in international careers (16\%), often migrating to Canada, Australia, the USA and other countries with liberal policies on in-migration of highly qualified labour from the south. Many report employment change from government to the NGO sector after graduating. Main assets of the programme are reported to be the interdisciplinary focussing, enabling candidates a broad perspective in their management repertoire. Thirty-eight of the candidates report being able to influence policy-making at a national level, while $26 \%$ report also influencing policy-making at regional levels of governance. Our main experience is that most of our students have benefited in general by having a M.Sc. certificate, but also that the perspectives taught have given particular advantages, especially in the more applied NGO and public sectors, and perhaps somewhat less in research careers in universities.

\section{Concluding Remarks and Implications for Forestry}

Crafting interdisciplinarity explicitly is not easy. Over 20 years we have struggled to develop a profile promoting such ventures, within a "disciplinary approach to interdisciplinarity." Linking disciplines closer and more explicitly in learning processes, merging interdisciplinarity closer to problembased, empirical challenges, contrasting it with other modes of local knowledgeing and action develops sound inter- and transdisciplinary approaches. This is also in line with more recent research in this field that merges socio-cultural and phenomenological thinking.

Interdisciplinarity as a process encompasses maturing and self-reflection on one's own perspectives and culture of learning and knowing. Developing candidates' abilities to "select, translate and integrate knowledge from different disciplines within coherent framework" is crucial in this context.

Forestry as an example of natural resource management is, in itself, not one discipline, but lends itself to combinations of disciplines and is better described as a field where, for example,disciplines such as biologists, ecologists, technologists and economists meet. Over time and through regular interactions in research and education, common grounds are established, and communication moves and joint work takes place quite freely, such as between forest economists and forest managers. An interesting observation is still that much of this communication and dialogue is not explicit or expressed, and challenges of communication are thus often underplayed.
However, emerging trends within forestry as a sector may force such dialogue to become more predominant and more explicit in the years to come. Modern forestry in developed countries is increasingly becoming less production- or monopurpose oriented and more multipurpose-oriented. The production sphere itself has been infiltrated by demands for delivery of public goods - environmental certification, biodiversity conservation, carbon sequestration, outdoor recreation and multipurpose uses of various types. As a further consequence,

The number and types of actors and institutions involved in forest management is rapidly changing.

Thus the competence of tomorrows' foresters has to change and more focus must be placed on educating change agents, facilitating not only multipurpose use of forests, but also candidates able and willing to address social issues and interactions among actors with often substantial degree of conflicting perspectives and interests. In this light, we believe that future education programmes have a considerable challenge in explicitly developing such proficiency of candidates.

The present competence of candidates with forestry backgrounds to meet such challenges is not non-existent, but it is more "common-sense, tacit and experience-based" and also often less theoretically grounded. Our experience is that giving candidates good social science theoretical knowledge provides them with a framework for practical and natural science knowledge and, in particular, supports their self-reflection and their personal learning and growth processes.

\section{References}

Apostel, L., G. Berger, A. Briggs and G. Machaud. 1972. Interdisciplinarity, Problems of Teaching and Research in Universities. Centre for Research and Innovation. OECD, Paris.

Bernstein, R.1983. Beyond Objectivism and Relativism. Basil and Blackwell, London.

Boden, M. 1996. What is Interdisciplinarity? In R. Cunningham (ed.). Euroscientia Conference. Interdisciplinarity and the Organisation of Knowledge in Europe. EU.

Bordieu, P. 1977. Outline of a Theory of Practice. Cambridge University Press. Cambridge.

Brun, H. 2000. Epistemic encounters. Intra- and Interdisciplinary Analyses of Human Action, Planning practices and Technological Change. Humanecologiska Skrifter.18.Gøteborgs Universitet. Dept. of Interdisciplinary Studies.

Brun. H., R. Langlais and N. Janasik. 2002. Transepistemic Communication and Innovation: A Conceptual Platform. Technology, Society and Environment. 3/2002. Helsinki University of Technology, Laboratory of Environmental Protection.

Dreyfus, H. and S. Dreyfus. 1986. Mind over Machine. The Power of Human Institutions and Expertise in the Era of the Computer. Free Press, New York.

Furnham, A.S. 1988. Lay Knowledge. Everyday Understanding of Problems in the Social Sciences. Pergamon Press, New York.

Gibbens, M., C. Limoges, H. Nowotny, S. Scwartzman,P. Scott and M.Trow. 1994.The New Production of Knowledge. The Dynamics of Science and Research in Contemporary Societies. Sage Publication. London.

Grimble, R., M. Chan, J. Aglionby and J. Quan. 1995. Trees and Trade-offs: A Stakeholder Approach to Natural Resource Management. IIED. Gatekeeper Series No.52. London

Heidegger, M. 1977. Hebel: der Hausfreund. Nekse, Pfullingen. Husserl, E. 1913. Logische Untersuchungen. Max Niemeyer, Halle.

Klein, J. T. 1990. Interdisciplinarity. History, Theory and Practice. Wayne State University Press, Detroit. 
Klein, J. T. 1996. Crossing Boundaries. Knowledge, Disciplinarities and Interdisciplinarities. University Press of Virginia, Charlottesville and London.

Knorr-Cetina, K. 1981. The Manufacture of Knowledge. An Essay on the Constructivist and Contextual Nature of Science. Pergamont Press, Oxford.

Kuhn, T. 1969. The Structure of Scientific Revolutions. International Encyclopedia of Unified Science. University of Chicago Press.

Latour, B. and S. Woolgar. 1986. Laboratory life: the construction of scientific facts. Princeton paperbacks. Princeton University Press, Princeton, N.J.

Lattuca, L.R. 2002. Learning Interdisciplinarity. Socio-Cultural Perspectives on Academic Work. The Journal of Higher Education 73(6): 711-739.

Long, N. and A.Long. 1992. Battlefields of Knowledge. The Interlocking of Theory and Practice in Social Research and Development. Routledge. London.

Molander, B. 1996. Kunnskap i Handling. Daidalos, Gøteborg. Polanyi, M. 1966. The Tacit Dimension. Routledge and Kegal Paul, London.

Randall, A. 1987. Resource Economics. An Economic Approach to Natural Resource and Environmental Policy. John Wiley and Son, New York.
Vedeld, P. and E. Krogh. 2000. Rationality in the Eye of the Actor Economists and Natural Scientists in a Discourse over Environmental Taxes, in Soil and Water Conservation Policies: Successes and Failures. Ed. Ted L. Napier, Silvana M. Napier, and Jiri Tvrdon. Soil and Water Conservation Society Press. Ankeny, Iowa.

Vedeld, P. 1994. Interdisciplinarity and the Environment. Neoclassical Economic and Ecological Perspectives on the Use of Natural resources. Ecological Economics 10: 1-13.

Relke, D. 1994. Feminist Pedagogy and the Integration of Knowledge, Towards a More Interdisciplinary University. (webpage, University of Saskatchewan, http://www.usask.ca/wgst/journals/ conf3.htm)

Vedeld, P. and A. Vatn. 1999. Styre og Stell i Norsk Naturforvaltning. Makt, Politikk, Styring og Virkemiddelbruk.Discussion Paper 4.1999. Dept. of Economics and Social Sciences, NLH.

Waktola, A. and S. Dejene. 2004. Educating Change Agents. The Contribution of the Agricultural University of Norway (NLH) in Ethiopia and Eritrea. Ås. NLH. 177 p.

Whitley, R. 2000. The Intellectual and Social Organisation of the Sciences. Oxford University Press. 